\title{
Salinivibrio siamensis sp. nov., from fermented fish (pla-ra) in Thailand
}

Correspondence

Somboon Tanasupawat

Somboon.T@chula.ac.th

\author{
Nitcha Chamroensaksri, ${ }^{1}$ Somboon Tanasupawat, ${ }^{1}$ \\ Ancharida Akaracharanya, ${ }^{2}$ Wonnop Visessanguan, ${ }^{3}$ Takuji Kudo ${ }^{4}$ \\ and Takashi Itoh ${ }^{4}$
${ }^{1}$ Department of Microbiology, Faculty of Pharmaceutical Sciences, Chulalongkorn University, Bangkok 10330, Thailand
${ }^{2}$ Department of Microbiology, Faculty of Science, Chulalongkorn University, Bangkok 10330, Thailand
${ }^{3}$ National Center for Genetic Engineering and Biotechnology, Pathumthani 12120, Thailand
${ }^{4}$ Japan Collection of Microorganisms, RIKEN BioResource Center, 2-1 Hirosawa, Wako-shi, Saitama 351-0198, Japan

\begin{abstract}
A Gram-negative, facultatively anaerobic, moderately halophilic bacterium, strain ND1-1 ${ }^{\top}$, was isolated from fermented fish (pla-ra) in Thailand. The cells were curved rods, motile and nonendospore-forming. The novel strain grew optimally at $37{ }^{\circ} \mathrm{C}$, at $\mathrm{pH} 8$ and in the presence of $9-10 \%(w / v) ~ N a C l$. The predominant respiratory lipoquinone was Q-8. The major cellular fatty acids were $\mathrm{C}_{16: 0}$ and $\mathrm{C}_{12: 0}$. Polar lipid analysis revealed the presence of phosphatidylethanolamine, phosphatidylglycerol and diphosphatidylglycerol. The DNA G + C content was 49.0 mol\%. Comparative 16S rRNA gene sequence analyses indicated that strain ND1-1 ${ }^{\top}$ was closely related to Salinivibrio costicola, which comprises three subspecies, and Salinivibrio proteolyticus with gene sequence similarities of 98.3-98.6\%. Strain ND1-1 ${ }^{\top}$ showed low levels of DNA-DNA relatedness with $S$. costicola subsp. costicola JCM $15095^{\top}$ (33.2\%), $S$. costicola subsp. alcaliphilus DSM $16359^{\top}$ (38.4\%), S. costicola subsp. vallismortis JCM $15096^{\top}$ (59.7\%), and S. proteolyticus AF- $2004^{\top}$ (42.1\%). On the basis of the physiological and biochemical characteristics and the molecular data presented, strain ND1-1 ${ }^{\top}$ should be classified as a novel species of the genus Salinivibrio for which the name Salinivibrio siamensis sp. nov. is proposed. The type strain is ND1-1 ${ }^{\top}\left(=\mathrm{JCM} 14472^{\top}=\mathrm{PCU} 301^{\top}=\right.$ TISTR $\left.1810^{\top}\right)$.
\end{abstract}

The genus Salinivibrio is included in the family Vibrionaceae, belonging to the class Gammaproteobacteria of the phylum Proteobacteria. This genus was created for Vibrio costicola based on the significant phenotypic and genotypic differences between this species and other species of the genus Vibrio (Mellado et al., 1996). At present, the genus comprises two species, Salinivibrio costicola subsp. costicola (Smith, 1938; Garcia et al., 1987), S. costicola subsp. vallismortis (Huang et al., 2000), S. costicola subsp. alcaliphilus (Romano et al., 2005) and Salinivibrio proteolyticus (Amoozegar et al., 2008). Members of the genus Salinivibrio are moderately halophilic bacteria which are

Abbreviations: DPG, diphosphatidylglycerol; PE, phosphatidylethanolamine; PG, phosphatidylglycerol.

The GenBank/EMBL/DDBJ accession number for the 16S rRNA gene sequence of strain $\mathrm{ND} 1-1^{\top}$ is $\mathrm{AB} 285018$.

Additional phylogenetic trees constructed by the maximum-parsimony and maximum-likelihood methods are available with the online version of this paper. distributed in salted meats, brines and hypersaline environments and grow in the presence of $0-20 \% \mathrm{NaCl}$. During our investigation into halophilic bacteria in fermented fish in Thailand, strains of Lentibacillus juripiscarius and Lentibacillus halophilus from fish sauce (Namwong et al., 2005; Tanasupawat et al., 2006), Lentibacillus kapialis from fermented shrimp paste (Pakdeeto et al., 2007) and Piscibacillus salipiscarius from fermented fish (Tanasupawat et al., 2007) have been reported. In this paper, a Salinivibrio-like, moderately halophilic bacterium, strain $\mathrm{ND} 1-1^{\mathrm{T}}$, isolated from fermented fish (pla-ra), is described based on phenotypic, chemotaxonomic and genotypic characteristics, including DNA-DNA relatedness and 16S rRNA gene sequence analyses.

Strain ND1- ${ }^{\mathrm{T}}$ was isolated from a fermented fish product, pla-ra, which was collected from a market in Nakornnayok province, Thailand. Pla-ra contains $7.8-17.9 \% \mathrm{NaCl}(\mathrm{w} / \mathrm{v})$ and has a pH of 4.3-6.2 (Phithakpol et al., 1995). The 
novel strain was isolated from the sample by the spreadplate technique on agar plates of JCM medium no. 377 (containing $\mathrm{l}^{-1}: 100 \mathrm{~g} \mathrm{NaCl}, 5 \mathrm{~g}$ Casamino acids, $5 \mathrm{~g}$ yeast extract, 1 g glutamic acid, $2 \mathrm{~g} \mathrm{KCl}, 3 \mathrm{~g} \mathrm{C}_{6} \mathrm{H}_{5} \mathrm{Na}_{3} \mathrm{O}_{7} .2 \mathrm{H}_{2} \mathrm{O}$, $20 \mathrm{~g} \quad \mathrm{MgSO}_{4} \cdot 7 \mathrm{H}_{2} \mathrm{O}, 36 \mathrm{mg} \quad \mathrm{FeCl}_{2} .4 \mathrm{H}_{2} \mathrm{O}, \quad 0.36 \mathrm{mg}$ $\mathrm{MnCl}_{2} .4 \mathrm{H}_{2} \mathrm{O}, 20$ g agar; $\mathrm{pH} 7.2$ ) and incubated at $37{ }^{\circ} \mathrm{C}$ for 3-7 days. Cell shape, size and arrangement were examined on JCM medium no. 377 agar at $37^{\circ} \mathrm{C}$ for 3 days. The Hucker-Conn modification was used for Gram stain (Hucker \& Conn, 1923). Spore formation was examined on Gram-stained specimens. Critical-point-dried cells were observed by scanning electron microscopy. Flagella were examined as described by Forbes (1981) and observed by transmission electron microscopy.

The effects of various $\mathrm{NaCl}$ concentrations $(0,0.5$ and $1-$ $25 \%$, w/v with a $1 \%$ interval), initial $\mathrm{pH}$ values $(5-10$, with intervals of $1 \mathrm{pH}$ unit) and temperatures $\left(5-55{ }^{\circ} \mathrm{C}\right.$ with intervals of $1,1.5,2,2.5$ and $3{ }^{\circ} \mathrm{C}$ ) on the growth of the novel strain were investigated with JCM medium no. 377 broth (Namwong et al., 2005). Catalase and oxidase activity, aesculin hydrolysis, citrate utilization and nitrate reduction were determined as described by Barrow \& Feltham (1993). The hydrolysis of casein, gelatin, starch and Tween 80 and the activities of DNase and urease were determined as described by Namwong et al. (2005). Arginine decarboxylase activity was determined by using the medium reported by Thornley (1960). Acid production from carbohydrate was determined with the medium described by Leifson (1963) and the ability to utilize various compounds was examined in a mineral liquid medium as reported by Romanenko et al. (2003) supplemented with $10 \% \mathrm{NaCl}$. Growth under anaerobic conditions on agar plates with or without $1 \%(\mathrm{w} / \mathrm{v}) \mathrm{KNO}_{3}$ was performed in Gaspak (BBL) anaerobic jars. Additional enzyme activities were recorded after $24 \mathrm{~h}$ incubation with API ZYM strips (bioMérieux).

Antibiotic susceptibility was determined according to the conventional Kirby-Bauer method (Bauer et al., 1966). Plates were incubated at $37{ }^{\circ} \mathrm{C}$ for $48 \mathrm{~h}$ and the inhibition zone was interpreted according to the manufacturer's manual. For chemotaxonomic characterization, cell biomass was produced in JCM medium no. 377 at $37{ }^{\circ} \mathrm{C}$ for 3 days. Quinones were analysed using reversed-phase HPLC as described by Komagata \& Suzuki (1987). Polar lipids were extracted as described by Minnikin et al. (1984) and identified by two-dimensional TLC followed by spraying with appropriate detection reagents (Komagata \& Suzuki, 1987). For quantitative analysis of cellular fatty acid content, cell mass was harvested and fatty acid methyl esters (FAMEs) were prepared and identified according to the instructions of the Microbial Identification System (MIDI) (Sasser, 1990; Kämpfer \& Kroppenstedt, 1996).

Chromosomal DNA was isolated and purified from cells grown in JCM medium no. 377 according to the method of Saito \& Miura (1963). The DNA G + C content was determined by reversed-phase HPLC (Tamaoka \&
Komagata, 1984). DNA-DNA hybridization tests were conducted in microdilution well plates as reported by Ezaki et al. (1989). The 16S rRNA gene of the novel isolate was amplified, purified and sequenced as described by Namwong et al. (2005). The sequence determined was aligned with selected sequences obtained from the GenBank/EMBL/DDBJ database by using CLUSTAL_X version 1.83 (Thompson et al., 1997). The alignment was manually edited and positions with gaps and ambiguous bases were eliminated prior to the construction of the phylogenetic tree. Phylogenetic trees based on the neighbour-joining method (Saitou \& Nei, 1987), maximumparsimony and maximum-likelihood methods were constructed with the NJPlot program (Perrière \& Gouy, 1996) with MEGA4 v4 software (Tamura et al., 2007). The confidence values of branches of the phylogenetic tree were determined using bootstrap analyses (Felsenstein, 1985) based on 1000 resamplings.

Cells of strain ND1- ${ }^{\mathrm{T}}$ were Gram-negative, non-endospore-forming, curved rods, approximately $0.4-0.5 \times 2-$ $8 \mu \mathrm{m}$ after 3 days incubation at $37^{\circ} \mathrm{C}$ on JCM medium no. 377 agar (Fig. 1a). Cells were motile by means of a single polar flagellum (Fig. 1b). Colonies were round with entire edges, smooth, convex, opaque and cream-pigmented. The diameter of the colonies was $0.9-2.5 \mathrm{~mm}$. The results of the biochemical tests are listed in the species description and in Table 1. The novel isolate grew over a $\mathrm{pH}$ range of 5-9 (optimally at $\mathrm{pH} 8$ ), at $10-47{ }^{\circ} \mathrm{C}$ (optimally at $37^{\circ} \mathrm{C}$ ) and in $1-22 \%(\mathrm{w} / \mathrm{v}) \mathrm{NaCl}$ (optimally in $9-10 \%$ ), but not in $0.5 \% \mathrm{NaCl}$ or below. No growth was observed at or above $50{ }^{\circ} \mathrm{C}$. The novel strain grew under anaerobic conditions even if $\mathrm{KNO}_{3}$ was omitted from the medium. The novel strain contained Q-8 as the major respiratory lipoquinone. The major cellular fatty acids were $\mathrm{C}_{16: 0}(16.4 \%)$ and $\mathrm{C}_{12: 0}(14.0 \%)$. When analysed in this study using the same conditions, strain ND1-1 ${ }^{\mathrm{T}}$, S. costicola subsp. costicola JCM $15095^{\mathrm{T}}$, S. costicola subsp. vallismortis DSM $8285^{\mathrm{T}}$, S. costicola subsp. alcaliphilus JCM $15096^{\mathrm{T}}$ and S. proteolyticus AF- $2004^{\mathrm{T}}$ contained roughly the same fatty acid pattern, with a large amount of $\mathrm{C}_{16: 1} \omega 7 c$ and/or iso- $\mathrm{C}_{15: 0} 2-\mathrm{OH}$

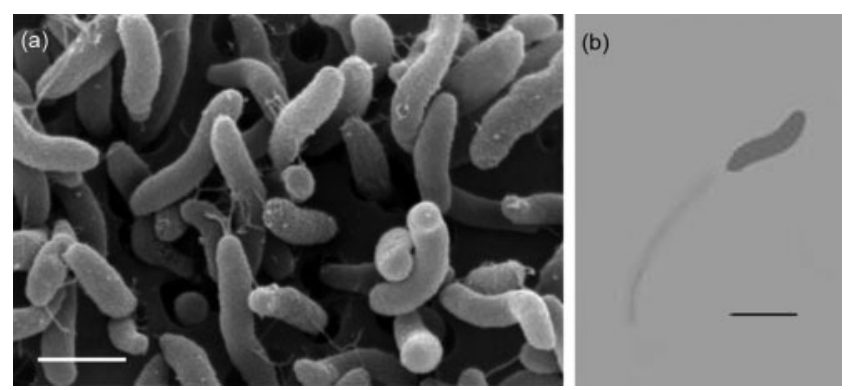

Fig. 1. (a) Scanning electron micrograph of cells of strain ND1-1 ${ }^{\top}$ grown on JCM medium no. 377 at $37{ }^{\circ} \mathrm{C}$. Bar, $1 \mu \mathrm{m}$. (b) Transmission electron micrograph of a cell of strain ND1-1 ${ }^{\top}$ showing the single polar flagellum. Bar, $2 \mu \mathrm{m}$. 
Table 1. Differential characteristics of strain $\mathrm{ND} 1-1^{\top}$ and related species of the genus Salinivibrio

Strains: 1 , ND1-1 ${ }^{\mathrm{T}} ; 2$, S. costicola subsp. costicola JCM $15095^{\mathrm{T}} ; 3$, S. costicola subsp. alcaliphilus DSM $16359^{\mathrm{T}} ; 4$, S. costicola subsp. vallismortis JCM $15096^{\mathrm{T}}$; 5, S. proteolyticus AF- $2004^{\mathrm{T}}$. +, Positive; w, weakly positive; -, negative; A, aerobe; FA, facultative anaerobe; ND, no data.

\begin{tabular}{|c|c|c|c|c|c|}
\hline Characteristic & 1 & 2 & 3 & 4 & 5 \\
\hline Colony colour & Cream & Cream & Cream-pink & Cream-white & Cream-white \\
\hline Oxygen requirement & FA & FA & A & $\mathrm{FA}$ & FA \\
\hline Flagellation & One polar flagellum & One polar flagellum* & $\mathrm{ND}$ & $\begin{array}{c}\text { One or two polar } \\
\text { flagella } \dagger\end{array}$ & One polar flagellum $\ddagger$ \\
\hline $\mathrm{NaCl}$ range $(\%, \mathrm{w} / \mathrm{v})$ & $1-22$ & $2-18$ & $2-22$ & $0-12.5$ & $1-17$ \\
\hline Optimum $\mathrm{NaCl}$ concentration (\%) & $9-10$ & 10 & 9 & 2.5 & 5 \\
\hline Temperature range $\left({ }^{\circ} \mathrm{C}\right)$ & $10-47$ & $15-45$ & $10-45$ & $20-50$ & $10-45$ \\
\hline Optimum temperature $\left({ }^{\circ} \mathrm{C}\right)$ & 37 & 34 & 37 & 37 & $32-35$ \\
\hline $\mathrm{pH}$ range & $5-9$ & $6-9$ & $6-10$ & $5.5-8.2$ & $5-9.5$ \\
\hline Optimum pH & 8 & 8 & 8 & 7.3 & $8-8.5$ \\
\hline Voges-Proskauer & + & + & - & + & + \\
\hline Nitrate reduction & - & - & + & - & - \\
\hline Esterase (C4) & - & + & - & + & $\mathrm{w}$ \\
\hline Naphthol-AS-BI phosphohydrolase & + & + & - & $\mathrm{w}$ & - \\
\hline$N$-acetyl- $\beta$-glucosaminidase & + & + & - & + & $\mathrm{w}$ \\
\hline \multicolumn{6}{|l|}{ Hydrolysis of: } \\
\hline Aesculin & - & - & + & - & - \\
\hline Starch & + & - & - & + & + \\
\hline L-Tyrosine & + & + & $\mathrm{W}$ & - & - \\
\hline \multicolumn{6}{|l|}{ Acid from: } \\
\hline Cellobiose & - & - & + & + & - \\
\hline D-Xylose & + & - & - & - & + \\
\hline \multicolumn{6}{|l|}{ Utilization of: } \\
\hline Cellobiose & - & + & - & + & - \\
\hline Crotonic acid & + & - & + & - & $\mathrm{ND}$ \\
\hline D-Fructose & - & - & - & + & + \\
\hline Glycine & + & - & + & - & + \\
\hline Malonic acid & - & - & + & - & + \\
\hline Succinate & + & - & + & - & + \\
\hline D-Xylose & + & - & - & - & - \\
\hline DNA G $+C$ content $(\mathrm{mol} \%)$ & 49 & 49.9 or $50.0^{*}$ & $49.3 \dagger$ & $50.0 \dagger$ & $49.5 \ddagger$ \\
\hline Source of isolation & Fermented fish & $\begin{array}{l}\text { Cured meat and } \\
\text { salterns }\end{array}$ & Saltish spring $\dagger$ & Death valley $\dagger$ & Hypersaline lake $\ddagger$ \\
\hline
\end{tabular}

${ }^{*}$ Data from Mellado et al. (1996) and Huang et al. (2000).

$\dagger$ Data from Romano et al. (2005).

¥Data from Amoozegar et al. (2008).

(25.3-35.7\%, summed feature 3) (Table 2). Phosphatidylethanolamine (PE), phosphatidylglycerol (PG) and diphosphatidylglycerol (DPG) were detected. The DNA $\mathrm{G}+\mathrm{C}$ content of the novel strain was $49.0 \mathrm{~mol} \%$.

A comparison of the $16 \mathrm{~S}$ rRNA gene sequence of strain ND1- $1^{\mathrm{T}}$ (1487 nucleotides) with those of other members of the family Vibrionaceae indicated that the novel strain was closely related to members of the genus Salinivibrio, showing $98.3 \%$ gene sequence similarity to $S$. costicola subsp. costicola NCIMB $701^{\mathrm{T}}, 98.3 \%$ to S. costicola subsp. alcaliphilus DSM $16359^{\mathrm{T}}, 98.2 \%$ to S. costicola subsp. vallismortis DSM $8285^{\mathrm{T}}$ and $98.6 \%$ to $S$. proteolyticus AF$2004^{\mathrm{T}}$ (Fig. 2).
In agreement with the phylogenetic assignment, the phenotypic properties of strain $\mathrm{ND} 1-1^{\mathrm{T}}$, such as cell morphology, $\mathrm{NaCl}$ range for growth, major lipoquinone composition, fatty acid profile and DNA G $+\mathrm{C}$ content, it is concluded that strain ND1-1 ${ }^{\mathrm{T}}$ can be placed within the genus Salinivibrio. Additionally, the $16 \mathrm{~S}$ rRNA gene sequence of strain $\mathrm{ND}_{1-1}{ }^{\mathrm{T}}$ contained the signature nucleotides found in the genus Salinivibrio (Mellado et al., 1996) and its secondary structure at positions 178-197 was more closely related to that of $S$. costicola subsp. vallismortis DSM $8285^{\mathrm{T}}$ and S. proteolyticus AF- $2004^{\mathrm{T}}$ than to those of $S$. costicola subsp. costicola NCIMB $701^{\mathrm{T}}$ and $S$. costicola subsp. alcaliphilus DSM $16359^{\mathrm{T}}$ as reported by Huang et al. (2000). However, strain ND1-1 ${ }^{\mathrm{T}}$ did not show 
Table 2. Cellular fatty acid content (\%) of strain ND1-1 ${ }^{\top}$ and related species of the genus Salinivibrio

Strains: $1, \mathrm{ND} 1-1^{\mathrm{T}} ; 2$, S. costicola subsp. costicola JCM $15095^{\mathrm{T}} ; 3, \mathrm{~S}$. costicola subsp. alcaliphilus DSM $16359^{\mathrm{T}} ; 4$, S. costicola subsp. vallismortis JCM $15096^{\mathrm{T}} ; 5$, S. proteolyticus AF- $2004^{\mathrm{T}} .-$, Not detected. Values are $\%$ of total cellular fatty acids.

\begin{tabular}{|lccccc|}
\hline Fatty acid & $\mathbf{1}$ & $\mathbf{2}$ & $\mathbf{3}$ & $\mathbf{4}$ & $\mathbf{5}$ \\
\hline Saturated straight-chain & & & & & \\
$\mathrm{C}_{12: 0}$ & 14.0 & 5.1 & 7.2 & 6.6 & 4.0 \\
$\mathrm{C}_{14: 0}$ & 8.1 & 3.7 & 2.8 & 6.8 & 3.6 \\
$\mathrm{C}_{16: 0}$ & 16.4 & 24.4 & 15.0 & 16.3 & 20.2 \\
$\mathrm{C}_{18: 0}$ & 1.5 & 1.2 & 1.6 & 1.4 & 3.0 \\
Unsaturated straight-chain & & & & & \\
$\mathrm{C}_{16: 1} \omega 9 c$ & 2.1 & 4.3 & 3.1 & 3.7 & 3.7 \\
$\mathrm{C}_{18: 1} \omega 5 c$ & - & - & - & - & 1.2 \\
$\mathrm{C}_{18: 1} \omega 7 c$ & 10.3 & 14.3 & 11.8 & 21.7 & 27.3 \\
$\mathrm{C}_{18: 1} \omega 9 c$ & 1.2 & 1.6 & 1.8 & 2.8 & 4.2 \\
Saturated branched-chain & & & & & \\
iso- $\mathrm{C}_{13: 0}$ & - & - & 4.6 & 1.4 & - \\
iso- $\mathrm{C}_{14: 0}$ & 1.7 & - & - & - & - \\
iso- $\mathrm{C}_{15: 0}$ & - & - & 1.3 & 1.9 & - \\
iso- $\mathrm{C}_{16: 0}$ & 2.8 & - & 1.9 & 1.7 & 1.4 \\
iso- $\mathrm{C}_{17: 0}$ & - & - & 2.0 & 1.2 & - \\
Hydroxylated fatty acids & & & & & \\
$\mathrm{C}_{12: 0} 3-\mathrm{OH}$ & 8.7 & 3.7 & 4.4 & 3.4 & 2.7 \\
Summed features & & & & & \\
2 & 5.4 & 4.6 & 6.3 & 5.8 & 3.4 \\
3 & 27.7 & 37.1 & 35.7 & 25.4 & 25.3 \\
& & & & & \\
\hline
\end{tabular}

${ }^{*}$ Summed features are groups of two or three fatty acids that can not be separated using the MIDI system. Summed feature 2 comprises iso- $\mathrm{C}_{16: 1}$ and/or $\mathrm{C}_{14: 0} 3-\mathrm{OH}$. Summed feature 3 comprises $\mathrm{C}_{16: 1} \omega 7 \mathrm{c}$ and/or iso- $\mathrm{C}_{15: 0} 2-\mathrm{OH}$.

clear affiliation with these two type strains in the 16S rRNA gene sequence-based trees based on the different algorithms (Fig. 2 and see Supplementary Figs S1 and S2 in IJSEM Online). The 16S rRNA gene sequence similarities between strain ND1- ${ }^{\mathrm{T}}$ and the four type strains (98.2$98.6 \%$ ) of the genus Salinivibrio did not suggest that strain ND $1-1^{\mathrm{T}}$ should be considered as a separate species (Stackebrandt \& Goebel, 1994). However, the DNA-DNA hybridization studies, conducted with three replicates, showed that strain ND1- $1^{\mathrm{T}}$ had low levels of DNA-DNA relatedness to $S$. costicola subsp. costicola JCM $15095^{\mathrm{T}}$ $(33.2 \%), \quad$ S. costicola subsp. alcaliphilus DSM $16359^{\mathrm{T}}$ $(38.4 \%)$, S. costicola subsp. vallismortis JCM $15096^{\mathrm{T}}$ $(59.7 \%)$ and S. proteolyticus AF- $2004^{\mathrm{T}}(42.1 \%)$. Strain ND1- $1^{\mathrm{T}}$ could be distinguished from the type strains of the genus Salinivibrio on the basis of the phenotypic properties shown in Table 1. Therefore, on the basis of phenotypic and genotypic properties, strain ND1- $1^{\mathrm{T}}$ represents a new member of the genus Salinivibrio, for which the name Salinivibrio siamensis sp. nov. is proposed.

\section{Description of Salinivibrio siamensis sp. nov.}

Salinivibrio siamensis (si.am.en'sis. N.L. masc. adj. siamensis pertaining to Siam, the old name of Thailand, where the strain was isolated).

Cells are Gram-negative, non-endospore-forming, curved rods, $0.4-0.5 \times 2-8 \mu \mathrm{m}$. Forms circular, convex, opaque, cream-coloured colonies $(0.9-2.5 \mathrm{~mm})$. Motile by means of a single polar flagellum. Facultatively anaerobic. Growth at $\mathrm{pH}$ values of $5-9$ (optimally at $\mathrm{pH} 8$ ), at $10-47{ }^{\circ} \mathrm{C}$ (optimally at $37{ }^{\circ} \mathrm{C}$ ) and in 1-22\% (w/v) $\mathrm{NaCl}$ (optimally in $9-10 \% \mathrm{NaCl}$ ), but no growth in the absence of $\mathrm{NaCl}$. Positive in tests for catalase, oxidase, hydrolysis of casein, gelatin, starch and L-tyrosine, for nitrate reduction, for the Voges-Proskauer reaction and for activities of arginine decarboxylase, acid phosphatase, alkaline phosphatase, cystine arylamidase, DNase, esterase lipase (C8), Nacetyl- $\beta$-glucosaminidase, $\alpha$-glucosidase, $\beta$-glucosidase, leucine arylamidase, naphthol-AS-BI-phosphohydrolase, trypsin and valine arylamidase. Negative result in tests for the hydrolysis of aesculin and Tween 80 , for citrate utilization, for activities of $\alpha$-chymotrypsin, esterase (C4), $\alpha$-fucosidase, $\alpha$-galactosidase, $\beta$-galactosidase, $\beta$-glucuronidase, lipase (C14), $\alpha$-mannosidase and urease, for $\mathrm{H}_{2} \mathrm{~S}$ production, for the methyl-red test and for indole formation. Acid is produced from D-fructose, D-galactose, D-glucose, glycerol, maltose, D-mannitol, D-mannose, ribose, sucrose, trehalose and D-xylose, but not from Larabinose, cellobiose, myo-inositol, lactose, melibiose, melezitose, raffinose, rhamnose, salicin or sorbitol. Utilizes L-alanine, crotonic acid, fumaric acid, glucoric acid, glycine, propionate, pyruvate, sodium glycolate, succinate and D-xylose. Slight growth in sodium hippurate, but does not utilize L-arginine, L-arabinose, betaine, cellobiose, citric acid, D-fructose, galactose, glucose, $p$ hydroxybenzoic acid, lactose, sucrose, malonic acid, Lornithine, sodium benzoate, sodium tartrate or sorbitol. The type strain is susceptible to ampicillin $(10 \mu \mathrm{g})$, chloramphenicol $(30 \mu \mathrm{g})$, nalidixic acid $(30 \mu \mathrm{g})$, novobiocin $(5 \mu \mathrm{g})$, rifampicin $(30 \mu \mathrm{g})$ and tetracycline $(30 \mu \mathrm{g})$, but resistant to bacitracin $(10 \mathrm{U})$, gentamicin $(10 \mu \mathrm{g})$, kanamycin $(30 \mu \mathrm{g})$ and neomycin $(30 \mu \mathrm{g})$. Q-8 is the major respiratory lipoquinone. Major cellular fatty acids are $\mathrm{C}_{16: 0}$ and $\mathrm{C}_{12: 0}$. PE, PG and DPG are the predominant polar lipids.

The type strain, ND1- $1^{\mathrm{T}} \quad\left(=\mathrm{JCM} \quad 14472^{\mathrm{T}}=\mathrm{PCU}\right.$ $301^{\mathrm{T}}=$ TISTR $1810^{\mathrm{T}}$ ), was isolated from fermented fish (pla-ra) in Thailand. The DNA G $+\mathrm{C}$ content of the type strain is $49.0 \mathrm{~mol} \%$.

\section{Acknowledgements}

We are very grateful to the Thailand Research Fund for a 2005 Royal Golden Jubilee Scholarship as a research grant to N. C. and in part by the Faculty of Pharmaceutical Sciences Research Grant (2005). The authors thank Dr Mohammad Ali Amoozegar for providing the type strain of Salinivibrio proteolyticus. 


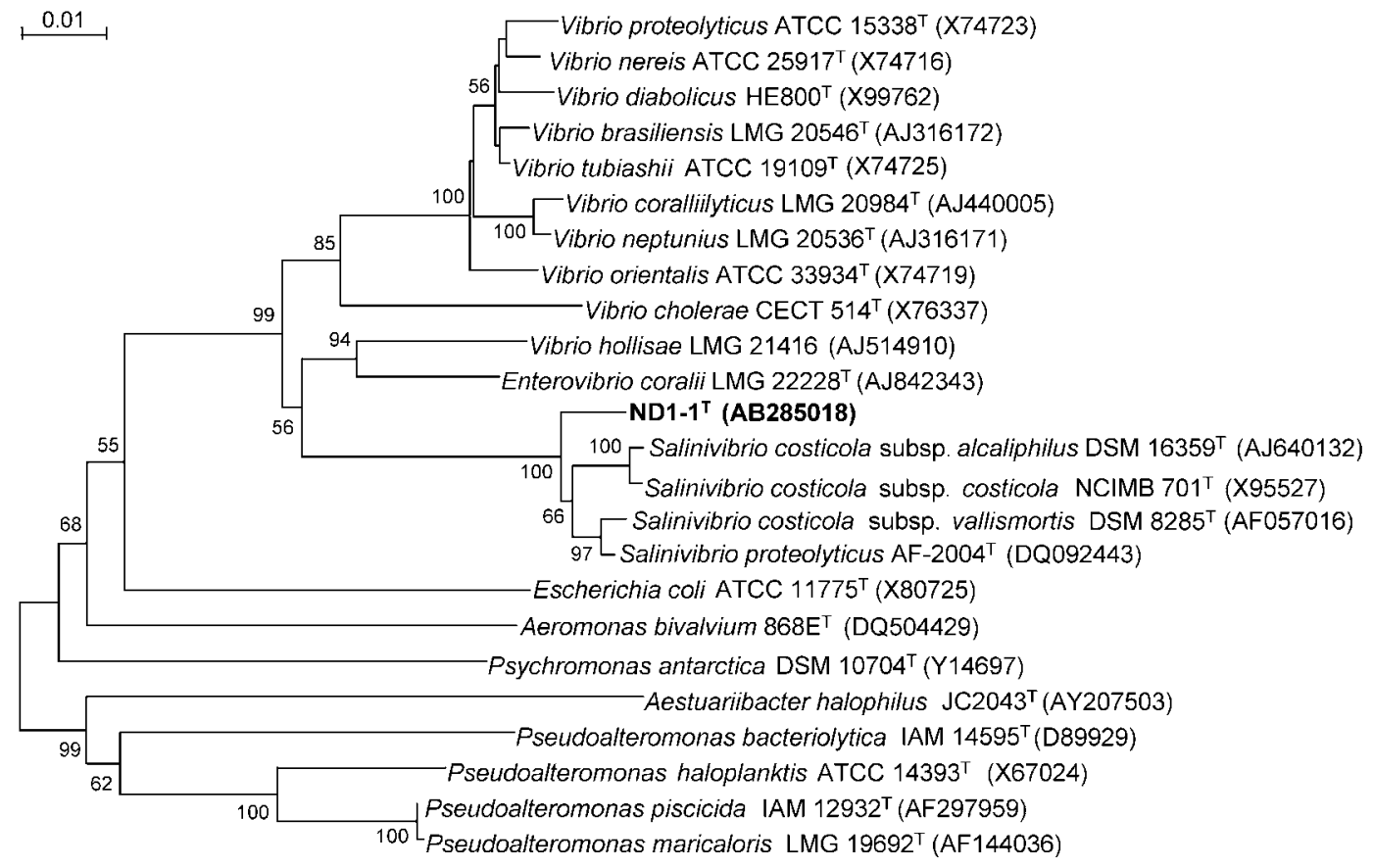

Fig. 2. Phylogenetic tree showing the relationships between strain ND1-1 ${ }^{\top}$, species of the genus Salinivibrio and related taxa based on 16S rRNA gene sequences. The branching pattern was generated by the neighbour-joining method. Bootstrap percentages $\geqslant 55 \%$, based on 1000 replications are shown at the nodes. Bar, 0.01 substitutions per nucleotide position.

\section{References}

Amoozegar, M. A., Schumann, P., Hajighasemi, M., Fatemi, Z. A. \& Karbalaei-Heidari, R. H. (2008). Salinivibrio proteolyticus sp. nov., a moderately halophilic and proteolytic species from a hypersaline lake in Iran. Int J Syst Evol Microbiol 58, 1159-1163.

Barrow, G. I. \& Feltham, R. K. A. (1993). Cowan and Steel's Manual for the Identification of Medical Bacteria, 3rd edn, 331 pp. Cambridge: Cambridge University Press.

Bauer, A. W., Kirby, W. M. M., Sherris, J. C. \& Turck, M. (1966). Antibiotic susceptibility testing by a standardized single disk method. Am J Clin Pathol 45, 493-496.

Ezaki, T., Hashimoto, Y. \& Yabuuchi, E. (1989). Fluorometric deoxyribonucleic acid-deoxyribonucleic acid hybridization in microdilution wells as an alternative to membrane filter hybridization in which radioisotopes are used to determine genetic relatedness among bacterial strains. Int J Syst Bacteriol 39, 224-229.

Felsenstein, J. (1985). Confidence limits on phylogenies: an approach using the bootstrap. Evolution 39, 783-791.

Forbes, L. (1981). Rapid flagella stain. J Clin Microbiol 13, 807-809.

Garcia, M. T., Ventosa, A., Ruiz-Berraquero, F. \& Kocur, M. (1987). Taxonomic study and amended description of Vibrio costicola. Int $J$ Syst Bacteriol 37, 251-256.

Huang, C. Y., Garcia, J. L., Patel, B. K. C., Cayol, J. L., Baresi, L. \& Mah, R. A. (2000). Salinivibrio costicola subsp. vallismortis subsp. nov., a halotolerant facultative anaerobe from Death Valley, and emended description of Salinivibrio costicola. Int J Syst Evol Microbiol 50, 615622.

Hucker, G. J. \& Conn, H. J. (1923). Method of Gram staining. N Y State Agric Exp Stn Tech Bull 93, 3-37.
Kämpfer, P. \& Kroppenstedt, R. M. (1996). Numerical analysis of fatty acid patterns of coryneform bacteria and related taxa. Can J Microbiol 42, 989-1005.

Komagata, K. \& Suzuki, K. (1987). Lipid and cell-wall analysis in bacterial systematics. Methods Microbiol 19, 161-207.

Leifson, E. (1963). Determination of carbohydrate metabolism of marine bacteria. J Bacteriol 85, 1183-1184.

Mellado, E., Moore, E. R. B., Nieto, J. J. \& Ventosa, A. (1996). Analysis of $16 \mathrm{~S}$ rRNA gene sequences of Vibrio costicola strains: description of Salinivibrio costicola gen. nov., comb. nov. Int J Syst Bacteriol 46, 817821.

Minnikin, D. E., O’Donnell, A. G., Goodfellow, M., Alderson, G., Athalye, M., Schaal, A. \& Parlett, J. H. (1984). An integrated procedure for the extraction of bacterial isoprenoid quinones and polar lipids. J Microbiol Methods 2, 233-241.

Namwong, S., Tanasupawat, S., Smitinont, T., Visessanguan, W., Kudo, T. \& Itoh, T. (2005). Isolation of Lentibacillus salicampi strains and Lentibacillus juripiscarius sp. nov., from fish sauce in Thailand. Int J Syst Evol Microbiol 55, 315-320.

Pakdeeto, A., Tanasupawat, S., Thawai, C., Moonmangmee, S., Kudo, T. \& Itoh, T. (2007). Lentibacillus kapialis sp. nov., from fermented shrimp paste in Thailand. Int J Syst Evol Microbiol 57, 364369.

Perrière, G. \& Gouy, M. (1996). WWW-Query: an on-line retrieval system for biological sequence banks. Biochimie 78, 364-369.

Phithakpol, B., Varanyanond, W., Reungmaneepaitoon, S. \& Wood, H. (1995). The Traditional Fermented Foods of Thailand. Kuala Lumpur: ASEAN Food Handling Bureau Level 3.

Romanenko, L. A., Uchino, M., Mikhailov, V. V., Zhukova, V. N. \& Uchimura, T. (2003). Marinomonas primoryensis sp. nov., a novel 
psychrophile isolated from coastal sea-ice in the Sea of Japan. Int J Syst Evol Microbiol 53, 829-832.

Romano, I., Gambacorta, A., Lama, L., Nicolaus, B. \& Giordano, A. (2005). Salinivibrio costicola subsp. alcaliphilus subsp. nov., a haloalkaliphilic aerobe from Campania Region (Italy). Syst Appl Microbiol 28, 34-42.

Saito, H. \& Miura, K. I. (1963). Preparation of transforming deoxyribonucleic acid by phenol treatment. Biochim Biophys Acta 72, 619-629.

Saitou, N. \& Nei, M. (1987). The neighbor-joining method: a new method for reconstructing phylogenetic trees. Mol Biol Evol 4, 406-425.

Sasser, M. (1990). Identification of bacteria by gas chromatography of cellular fatty acids. MIDI Technical Note 101. Newark, DE: MIDI Inc.

Smith, F. B. (1938). An investigation of a taint in rib bones of bacon. The determination of halophilic vibrios (n. spp.). Proc R Soc Queensl 49, 29-52.

Stackebrandt, E. \& Goebel, B. M. (1994). Taxonomic note: a place for DNA-DNA reassociation and $16 \mathrm{~S}$ rRNA sequence analysis in the present species definition in bacteriology. Int J Syst Bacteriol 44, 846-849.
Tamaoka, J. \& Komagata, K. (1984). Determination of DNA base composition by reversed-phase high-performance liquid chromatography. FEMS Microbiol Lett 25, 125-128.

Tamura, K., Dudley, J., Nei, M. \& Kumar, S. (2007). MEGA4: Molecular evolutionary genetics analysis (MEGA) software version 4.0. Mol Biol Evol 24, 1596-1599.

Tanasupawat, S., Pakdeeto, A., Namwong, S., Thawai, C., Kudo, T. \& Itoh, T. (2006). Lentibacillus halophilus sp. nov., from fish sauce in Thailand. Int J Syst Evol Microbiol 56, 1859-1863.

Tanasupawat, S., Namwong, S., Kudo, T. \& Itoh, T. (2007). Piscibacillus salipiscarius gen. nov., sp. nov., a moderately halophilic bacterium from fermented fish (pla-ra) in Thailand. Int J Syst Evol Microbiol 57, 1413-1417.

Thompson, J. D., Higgins, D. G. \& Gibson, T. J. (1997). The CLUSTAL_X windows interface: flexible strategies for multiple sequence alignment aided by quality analysis tools. Nucleic Acids Res 25, 4876-4882.

Thornley, M. J. (1960). The differentiation of Pseudomonas from other Gram-negative bacteria on the basis of arginine metabolism. J Appl Microbiol 23, 37-52. 